\title{
Interruption of CXCL13-CXCR5 Axis Increases Upper Genital Tract Pathology and Activation of NKT Cells following Chlamydial Genital Infection
}

\author{
Janina Jiang ${ }^{19}$, Ouafae Karimi ${ }^{49}$, Sander Ouburg ${ }^{4}$, Cheryl I. Champion ${ }^{1}$, Archana Khurana ${ }^{6}$, \\ Guangchao Liu', Amanda Freed', Jolein Pleijster', Nora Rozengurt ${ }^{1,3}$, Jolande A. Land', \\ Helja-Marja Surcel ${ }^{8}$, Aila' Tiitinen $^{9}$, Jorma Paavonen ${ }^{9}$, Mitchell Kronenberg ${ }^{6}$, Servaas A. Morré ${ }^{4,5}$, \\ Kathleen A. Kelly ${ }^{1,2 *}$
}

1 Department of Pathology and Laboratory Medicine, David Geffen School of Medicine, University of California Los Angeles, Los Angeles, California, United States of America, 2 California NanoSystems, University of California Los Angeles, Los Angeles, California, United States of America, 3 CURE DDRC Morphology and Images Core, University of California Los Angeles, Los Angeles, California, United States of America, $\mathbf{4}$ Laboratory of Immunogenetics, Department of Medical Microbiology and Infection Control, VU University Medical Center, Amsterdam, The Netherlands, 5 Institute of Public Health Genomics, Department of Genetics and Cell Biology, Research Institutes, School of Public Health and Primary Care (CAPHRI) and Growth and Development (GROW), Faculty of Health, Medicine \& Life Sciences, University of Maastricht, Maastricht, The Netherlands, $\mathbf{6}$ La Jolla Institute for Allergy and Immunology, La Jolla, California, United States of America, 7 Department of Obstetrics and Gynaecology, University Medical Center Groningen, Groningen, The Netherlands, 8 National Institute for Health and Welfare, Kastelli Research Centre, Oulu, Finland, 9 Department of Obstetrics and Gynecology, University Hospital, University of Helsinki, Helsinki, Finland

\begin{abstract}
Background: Regulation of immune responses is critical for controlling inflammation and disruption of this process can lead to tissue damage. We reported that CXCL13 was induced in fallopian tube tissue following C. trachomatis infection. Here, we examined the influence of the CXCL13-CXCR5 axis in chlamydial genital infection.

Methodology and Principal Findings: Disruption of the CXCL13-CXCR5 axis by injecting anti-CXCL13 Ab to BALB/C mice or using $\mathrm{Cxcr5}-/-$ mice increased chronic inflammation in the upper genital tract (UGT; uterine horns and oviducts) after Chlamydia muridarum genital infection (GT). Further studies in Cxcr5-/- mice showed an elevation in bacterial burden in the GT and increased numbers of neutrophils, activated DCs and activated NKT cells early after infection. After resolution, we noted increased fibrosis and the accumulation of a variety of T cells subsets (CD4-IFN $\gamma$, CD4-IL-17, CD4-IL-10 \& CD8TNF $\alpha$ ) in the oviducts. NKT cell depletion in vitro reduced IL-17 $\alpha$ and various cytokines and chemokines, suggesting that activated NKT cells modulate neutrophils and DCs through cytokine/chemokine secretion. Further, chlamydial glycolipids directly activated two distinct types of NKT cell hybridomas in a cell-free CD1d presentation assay and genital infection of Cd1d-/- mice showed reduced oviduct inflammation compared to WT mice. CXCR5 involvement in pathology was also noted using single-nucleotide polymorphism analysis in C. trachomatis infected women attending a sub-fertility clinic. Women who developed tubal pathology after a C. trachomatis infection had a decrease in the frequency of CXCR5 SNP $+10950 \mathrm{~T}>\mathrm{C}$ (rs3922).

Conclusions/Significance: These experiments indicate that disruption of the CXCL13-CXCR5 axis permits increased activation of NKT cells by type I and type II glycolipids of Chlamydia muridarum and results in UGT pathology potentially through increased numbers of neutrophils and T cell subsets associated with UGT pathology. In addition, CXCR5 appears to contribute to inter-individual differences in human tubal pathology following $C$. trachomatis infection.
\end{abstract}

Citation: Jiang J, Karimi O, Ouburg S, Champion Cl, Khurana A, et al. (2012) Interruption of CXCL13-CXCR5 Axis Increases Upper Genital Tract Pathology and Activation of NKT Cells following Chlamydial Genital Infection. PLoS ONE 7(11): e47487. doi:10.1371/journal.pone.0047487

Editor: David M. Ojcius, University of California Merced, United States of America

Received May 16, 2012; Accepted September 12, 2012; Published November 26, 2012

Copyright: (c) 2012 Jiang et al. This is an open-access article distributed under the terms of the Creative Commons Attribution License, which permits unrestricted use, distribution, and reproduction in any medium, provided the original author and source are credited.

Funding: The work was sponsored by grants from the National Institutes of Health, AI026238 (KAK) and Al45053 (MK) plus a sponsored research award from Abraxis Bioscience, Inc (KAK). The human studies were performed by members of the EpiGenChlamydia Consortium funded by the European Commission within the Sixth Framework Program through contract no. LSHG-CT-2007-037637. The funders had no role in study design, data collection and analysis, decision to publish, or preparation of the manuscript.

Competing Interests: The authors have read the journal's policy and have the following conflicts: KAK received a sponsored research award from Abraxis Bioscience, Inc. This does not alter the authors' adherence to all the PLOS ONE policies on sharing data and materials.

*E-mail: kkelly@mednet.ucla.edu

9 These authors contributed equally to this work.

\section{Introduction}

Chlamydia trachomatis, an obligate intracellular bacterium, causes the most cases of bacterial sexually transmitted infections (STIs) in the US resulting in about three million new cases annually [1-3]. Genital infection can lead to immune-mediated damage of the female reproductive organs and serious reproductive disability, 
including pelvic inflammatory disease (PID) that can result in chronic pelvic pain, ectopic pregnancy and infertility. Approximately $8 \%$ of females annually develop PID and this risk increases by $40-70 \%$ following re-infection [3,4]. Although female infection is easily detected and treated with antibiotics, treated individuals can acquire another infection in six months implicating repeated inflammatory insults as a cause of PID and infertility [5]. However, the mechanism(s) which causes PID and infertility following chlamydial genital infection is not known.

The mouse model of $C$. trachomatis genital infection (C. muridarum) is used to reveal the underlying mechanism(s) for developing immune-mediated damage of the female reproductive organs following STIs. It is known that C. muridarum bacteria cause genital tract (GT) infections which trigger development of protective immune responses but infection also results in GT inflammation and is associated with neutrophils and CD8 cells that produce $\mathrm{TNF} \alpha[6-8]$. Immune-mediated damage can be quantitated in the mouse, is a measure of infertility and is termed upper genital tract (UGT) pathology [9]. The majority of genital infections are resolved by development of an anti-chlamydial Thl response $[10,11]$.

NKT cells are innate-like $\mathrm{T}$ cells that rapidly respond to infection and regulate microbial immunity including C. muridarum lung and GT infection [12-15]. NKT cells require TCR ligation for activation to secrete an array of cytokines and chemokines $[16,17]$. In addition, they also modulate immune outcomes by interacting with dendritic cells (DC), NK cells, T, B cells and plasmacytoid DC by cell-cell contact [12]. NKT cells are activated with CDld-restricted glycolipid antigens and are classified into two subsets $[16,18]$. Type I (classical or invariant, iNKT) NKT cells express an invariant TCR, V $\alpha 14-\mathrm{J} \alpha 18$ in the mouse and the homolog, V $\alpha 24-\mathrm{J} \alpha 18$, in humans [19]. The antigen receptors expressed by iNKT cells in mice and humans recognize exogenous glycolipids expressed by microbes that contain a common glycolipid structure, including the GLXA glycolipid of C. muridarum [13]. Type II NKT cells are less studied than iNKT cells, have a more diverse in TCR repertoire and do not recognize the prototypical iNKT cell activating antigen, $\alpha$-galactosylceramide $(\boldsymbol{\alpha}$-GalCer) [19].

Chemokines have an established role in homing and directional migration but also have additional roles in the immune system including; development of lymphoid organs, cognate interaction, cell signaling, differentiation, cell survival and serve as growth factors. Likewise, the chemokine CXCL13 has additional roles beyond migration and disruption of the CXCL13-CXCR5 axis occurs in many diseases as well as chronic infections [20-23]. We recently reported that $C$. trachomatis induces expression of CXCL13, the ligand for CXCR5, in human fallopian tube tissue following infection [24]. Surprisingly, the mRNA for this chemokine was induced at higher levels (30-fold over mock infected controls) in comparison to more than 90 other cytokines and chemokines analyzed including IFN $\gamma$. In this report, we examined the influence of the CXCL13-CXCR5 axis in chlamydial genital infection.

\section{Materials and Methods}

\section{Ethics Statement}

All experimental animal procedures were approved by the UCLA Office of Animal Research Oversight; Chancellor's Animal Research Committee which adheres to the national guidelines with the Public Health Service Policy on Human Care and Use of Animals (PHS Policy) and USDA Animal Welfare Regulation (AWRs) with assurance number A3196. All procedures were designed to provide for maximum comfort/minimal stress to the animals and cannot be further refined to minimize pain/distress since there are no less painful/distressful options available. The procedures are presently refined to provide the best possible scientific methodologies available. The animals are monitored for signs of agitation (licking, biting or guarding the vaginal region), failure to groom, loss of appetite, or marked weight loss $(>10 \%)$. If noted, the Attending Veterinarian is contacted for his/her recommendation for treatment. Human subjects analyzed for CXCR5 SNP typing were consented by a written informed consent form and approved by review boards at Vrije Universiteit, Amsterdam, The Netherlands and University of Helsinki.

\section{Animals, Chlamydia, anti-CXCL13 treatment and Challenge of mice}

BALB/c and C57BL/6 mice (Jackson Labs, Bar Harbor, Maine) or a breeding colony was established with $C x c r 5-/-$ mice (8 generations in C57BL/6) obtained from Martin Lipp, Delbrück-Center for Molecular Medicine, Berlin, Germany. $\mathrm{BALB} / \mathrm{c}$ mice were given two intraperitoneal injections of affinity purified goat IgG anti-CXCL13 or control goat IgG (R\&D Systems, Minneapolis, Minn) on days -1 and 2 of infection [25]. Chlamydia muridarum was grown on confluent McCoy cell monolayers, purified on Renograffin gradients and stored at $-80^{\circ} \mathrm{C}$ in SPG buffer (sucrose-phosphate-glutamine) as previously described [26]. Mice were hormonally synchronized by subcutaneous infection with $2.5 \mathrm{mg}$ of medroxyprogesterone acetate (Depo Provera, Upjohn, Kalamazoo, MI) in $100 \mu \mathrm{L}$ saline 7 days prior to a vaginal challenge with $1.5 \times 10^{5}$ IFUs of $C$. muridarum under anesthetization. Mice were 5-6 weeks old at the time of infection. Infection was monitored by measuring infection forming units (IFU) from cervical-vaginal swabs (Dacroswab Type 1, Spectrum Labs, Rancho Dominguez, CA) as previously described [27].

\section{Histology, Hematoxylin \& Eosin and Trichrome stain}

GT's were removed at day 49 post-infection, fixed in $10 \%$ formalin overnight, and subsequently, 70\% ethanol. Tissues were embedded en bloc in paraffin, sectioned $(5 \mu \mathrm{m})$, and stained with hematoxylin and eosin. A second set was stained with hematoxylin and eosin followed by Gormori trichrome [28]. Two hematoxylin and eosin $(\mathrm{H} \& \mathrm{E})$ sections per mouse were masked and scored for chronic inflammatory cells or mononuclear cells [29]: $0=$ normal, $1=$ rare foci, $2=$ scattered ( 1 to 4 ) aggregates, $3=$ numerous aggregates $(>4), 4=$ severe diffuse infiltration. Two slides were scored and averaged per oviduct. Trichrome stained slides were used to access fibrosis and were masked and counted using the following scoring scheme: $1+=$ bright blue staining collagen fibers surrounding $<33 \%$ of oviducts; $2+=$ bright blue staining collagen fibers surrounding $34-66 \%$ of oviducts; $3+=$ bright blue staining collagen fibers surrounding $>66 \%$ of oviducts. Naïve mice score from 1-2+. Two slides were scored and averaged per oviduct.

\section{Lympholyte isolation and FACS identification}

Spleen (Spl), iliac lymph nodes (ILN), GTs or oviducts were harvested from individual mice and single cell suspensions prepared by dissociating the lymphocytes. Lymphocyte isolation from GTs or oviducts was carried out as described [30]. Briefly, the entire GT or oviduct was removed and cut into $0.5 \mathrm{~cm}$ pieces that were then rinsed with $\mathrm{Ca}^{2+} \mathrm{Mg}^{2+}$-free Hanks' balanced salt solution (HBSS). The tissue was incubated in a mixture of $5 \mathrm{mM}$ EDTA in HBSS at $37^{\circ} \mathrm{C}$ for two 15 min periods with gentle stirring. The tissue was then incubated with RPMI 1640 containing $2 \%$ bovine calf serum, antibiotics, $25 \mathrm{mM}$ HEPES 
and $1.5 \mathrm{mg} / \mathrm{mL}$ collagenase (Sigma, USA) and incubated at $37^{\circ} \mathrm{C}$ with stirring for two periods of $1 \mathrm{hr}$. The isolated cells were pooled together and separated on a 40/75\% discontinuous Percoll gradient (Pharmacia, Piscataway, N.J.) centrifuged at $2000 \mathrm{rpm}$ at $22^{\circ} \mathrm{C}$ for $20 \mathrm{~min}$. Mononuclear cell pellets were resuspended in RPMI 1640 at $4{ }^{\circ} \mathrm{C}$ until used. For intracellular cytokine staining, lymphocytes isolated from different organs were incubated in RPMI 1640 in the presence of PMA and ionomycin. Brefeldin A (Sigma) was added $4 \mathrm{hr}$ before the end of culture. For surface staining, cells were directly stained with various FACS antibodies after isolation and without in vitro culture. The cells were then stained with fluorochrome-labeled antibodies against CD3 (clone 145-2C11), GD4 (clone GK1.5), CD8 (clone 53-6.7), Gr-1 (clone RB6-8C5), NK1.1, (clone PK136), CD11c (clone N418), CD19 (clone 6D5), GD1lb (clone...M1/70), CD40 (clone 3/23), CD69 (clone H1.2F3) and CXCR5 (clone 2G8) (Biolegend) and $\alpha$ GalCer-CD1d-tetramer for $20 \mathrm{~min}$ on ice [31]. After being washed, the cells were incubated with Cytofix/Cytoperm (BD Biosciences) for $1 \mathrm{hr}$ and the stained with fluorochrome-conjugated anti-IFN- $\gamma$ (clone XMG1.2), IL-10 (clone ES5-16E3), TNF $\alpha$ (clone MP6-XT22) or IL-17 (clone TC11-18H10.1) antibody (Biolegend) for $20 \mathrm{~min}$ on ice, washed again, resuspended in Cell Fix solution, and analyzed on SORP BD LSR II (Beckman Dickinson, Franklin Lakes, NJ).

\section{NKT cell depletion, CD1d blocking and in vitro cell culture}

Spleens were treated with iNKT depletion, CDld blocking, iNKT depletion+CDld blocking, or with $\alpha$-GalCer $(250 \mathrm{ng} / \mathrm{mL})$ and untreated cells served as control. To deplete iNKT cells, splenocytes were stained with PE- $\alpha$-GalCer-CDld-tetramer on ice for $30 \mathrm{~min}$ and the stained iNKT cells were depleted by using EasySep Mouse EP Positive Selection Kit (Stemcell Technologies, Canada) according to manufacturer's protocol. The depletion efficiency was greater than $90 \%$ as tested by FACS analysis. To deplete CDld presenting cells, the cells were treated with antiCDld monoclonal antibody (clone $1 \mathrm{Bl})(10 \mu \mathrm{g} / \mathrm{mL})$ or isotype control for $30 \mathrm{~min}$ prior to culture. Cells were then cultured in RPMI 1640 in presence of C. muridarum EB for 3 days and supernatants were stored at $-80^{\circ} \mathrm{C}$.

\section{Cytokine measurement and multi-analyte ELISArray}

IFN $\gamma$ was measured by ELISA (R\&D Systems) in supernatants from cell cultures following storage $-80^{\circ} \mathrm{C}$. IL-1 $\beta$, IL-12, IL-6, CGL3, GCL4, GCL2, IL-17 $\alpha$, CXCL12, CCL22, CGL5 and $\mathrm{TNF} \alpha$ were analyzed by multi-analyte ELISArray kit (SABiosciences, Frederick, MD) in supernatants from cell cultures following storage $-80^{\circ} \mathrm{C}$. The assays were carried out according to manufacturer's protocol and calibrated standards were provided by the manufacturer.

\section{In vitro CD1d presentation assay}

We used the method of Kinjo et. al. [32] and first coated a 96well flat bottom plate with soluble mCDld protein for $1 \mathrm{~h}$ at $37^{\circ} \mathrm{C}$. After washing and blocking, various concentrations of sonicated $C$. muridarum was added to wells and incubated for $24 \mathrm{~h}$ at $37^{\circ} \mathrm{C}$. $\alpha$ GalCer and vehicle served as positive and negative controls, respectively. The wells were washed and $5 \times 10^{4}$ murine invariant NKT hybridoma cells: 1.2, 1.4, or variant NKT hybridoma 19 were added and cultured overnight (16-20 hr). IL-2 released in the supernatant upon activation was measured by ELISA (BD Pharmingen).

\section{Patients}

Dutch STD cohort. Women of Dutch Caucasian origin $(n=543)$ visiting the STD outpatient clinic in Amsterdam, the Netherlands during the period of July 2001-December 2004. Participants were asked to sign an informed consent and fill out a questionnaire, regarding their complaints at that moment, varying from increased discharge, having bloody discharge during and/or after coitus, recent abdominal pain (not gastrointestinal or menses related) and/or dysuria. A cervical swab was taken for the detection of $C$. trachomatis-DNA by PCR [33]. Peripheral venous blood was collected for the analysis of $\mathrm{IgG}$ antibodies against C. trachomatis (Medac Diagnostika mbH, Hamburg, Germany). A titre of $\geq 1: 50$ was considered positive. Those who had no Chlamydia infection, based on negative $C$. trachomatis-DNA and without $C$. trachomatis serology, served as controls. Infections with Candida albicans, Neisseria gonorrhoea, Trichomonas vaginalis and Herpes simplex virus 1 or 2 were also documented. Microorganism detection was done according to methods described by Ouburg et al. [34].

Dutch Subfertility cohort. The study cohort included 259 Dutch Caucasian women who presented with subfertility at the Research Institute Growth and Development and the Department of Obstetrics and Gynaecology, University of Maastricht, The Netherlands, as part of a larger study. This subfertility group has been described elsewhere [34,35]. For this study, women with or without clinically defined tubal pathology $(n=56)$ were selected to have the clearest clinical definition. Tubal pathology was defined as extensive periadnexal adhesions and/or distal occlusions of one or both tubes. Chlamydial antibodies were assessed by indirect microimmunofluorescence (MIF) test for anti-C. trachomatis IgGantibodies. A positive CT IgG MIF test was defined as a titer $\geq 1: 32$.

Finland study population. The study population consisted of 114 infertile women who had attended the In Vitro Fertilization Unit, Department of Obstetrics and Gynaecology, Helsinki University Hospital, Helsinki, Finland in 1990-2005. Controls were selected from a group of 176 female blood donors. The selected cases consisted of 24 C. trachomatis-positive women with laparoscopically verified tubal factor infertility (TFI) for the best clinical definition. The other women, the control group consisted of female blood donors whose buffy coat specimens were provided by the Finnish Red Cross Blood Transfusion Service (Oulu, Finland). The specimens were transported to the laboratory at room temperature within $24 \mathrm{~h}$ of donation. The specific immune responses of $C$. trachomatis have been described elsewhere and $C$. trachomatis status was determined by $C$. trachomatis specific serology and cell stimulation as described previously [36].

Gxcr5 SNP detection. Genomic DNA was extracted from peripheral blood using the MagNaPure LC isolator as described [34]. A healthy Dutch Caucasian control group $(\mathrm{n}=130)$ was included to assess the general frequency of the three studied SNPs CXCR5 +3439 C>T (rs497916), +9086 $\mathrm{T}>\mathrm{C} \quad(\mathrm{rs} 12363277)$, $+10950 \mathrm{~T}>\mathrm{C}(\mathrm{rs} 3922)$ in the general Dutch Caucasian population. The CXCR5 SNPs were determined using the standard TaqMan analysis. The three CXCR5 SNPs tag $96.6 \%$ of the haplotypes, consisting of rs497916, rs566416, rs543524, rs12363277, rs613791, rs598207, rs3922, and rs676925. This haplotype spans $7 \mathrm{~KB}$ of the $\operatorname{cxcr} 5$ gene.

Statistics. Bonferroni's modified $t$-test and analysis of variance (ANOVA) was performed using GraphPad Prizm version 5.04, GraphPad Software (San Diego, CA). Groups were considered statistically different at $* \mathrm{p}<0.05$ and $* * \mathrm{p}<0.01$. Data are presented as mean $\pm \mathrm{SD}$ or SEM as indicated. Differences in 
human CXCR5 genotype and haplotype distributions were analyzed using $\chi^{2}$ and Fisher Exact test, where appropriate and $\mathrm{p}<0.05$ was considered statistically significant. CXCR5 haplotypes were inferred using PHASE v2.1.1 and SNPHAP.

\section{Results}

\section{Disruption of the CXCL13-CXCR5 axis alters bacterial burden in $\mathrm{CxCr} 5-/-$ mice}

We evaluated the chlamydial burden in the GT from vaginal swabs by using two models for disrupting the CXCL13-CXCR5 axis. In the first model, we blocked ligation of CXCL13 with its receptor, CXCR5, by administering anti-CXCL13 as reported [25]. As shown in Figure 1A, mice were given $200 \mu \mathrm{g}$ of polyclonal goat anti-CXCL13 and irrelevant polyclonal goat $\mathrm{Ab}$ the day prior to infection (d-1) and 2 days after infection (red arrows). This regimen did not produce any statistical difference in the course of infection between the groups although we noted that antiCXCL13 treated mice cleared infection a few days earlier than controls. This procedure does not show depletion of CXCL13 in ELISA assays (data not shown) and there is no assay to detect functional blocking in vivo [25]. We also examined Cxcr5-/- mice and found that there was a slight delay in resolution of infection and a significant increase in bacterial burden during the infection course compared to WT controls (Fig. 1B). Consistent with the increased bacterial burden we also found increases in early immune responders such as neutrophils, activated $\mathrm{CD} 40^{+}$ conventional DG (cDC) and activated CD69 ${ }^{+}$NKT cells in the GT (Fig. 1C-E) but no difference was seen in the number of plasmacytoid DC cells (data not shown) which also responds to $C$. muridarum genital infection [37]. Cxcr5-/- mice lack Peyer's patches, axillary, inguinal, parathymic, mediastinal and iliac lymph nodes but have facial, cervical, mesenteric lymph nodes and spleen $[38,39]$. Possibly, the lack of iliac lymph nodes could delay the appearance of Thl cells in the GT and also effect bacterial load. In support, we found that $C$. muridarum responsive Thl cells peak earlier on day 7 in WT mice compared to day 14 of Cxcr5/- mice (Fig. 1F).

\section{Disruption of the CXCL13-CXCR5 axis increased UGT pathology}

We evaluated UGT (uterine horns+oviducts) pathology in mice treated with anti-CXCL13 Ab and Cxcr5-/- mice by examining inflammatory scores in the UGT from hematoxylin and eosin stained slides and fibrosis from trichrome stained slides of oviducts after infection. Mice treated with anti-CXCL13 Ab and Cxcr5- / - mice had increased chronic inflammatory or mononuclear cell scores when harvested 49 days after infection (Fig. 2A). We also measured the amount of fibrosis seen in mesenchymal tissue from WT and Cxcr5-/- mice. The mesenchymal tissue surrounding oviducts from WT mice developed varying degrees of fibrosis after infection (asterisk) which was increased in Cxcr5 $-/-$ mice (arrows) (Fig. 2B). Marked fibrosis was also apparent in all Cxcr5-/- mice following infection (Fig. 3C). Although we did not note occluding fibrosis which is associated with infertility, oviduct dilation was also noted in Cxcr5-/- (arrowhead)(Fig. 2B).

\section{T cell subsets accumulate in the oviducts of $\mathrm{Cxcr5}-/-$ mice following infection}

After chlamydial genital infection had resolved, we performed flow cytometry on CD4 and CD8 lymphocyte subsets from oviducts of Cxcr5-/- and WT mice to identify the type of accumulating mononuclear cells. Figure $3 \mathrm{~A}$ shows representative dotplots of the subsets analyzed. We found a significant increase in all lymphocyte subsets analyzed in Cxcr5-/- mice which include; CD4-IFN- $\gamma$, CD4-IL-17, CD4-IL-10 and CD8-TNF- $\alpha$ (Fig. 4B). Larger increases were noted in CD4-IL-10 and CD8-TNF $\alpha$ subsets than the Th1 subset. Thus, mice lacking the CXCR5 chemokine receptor sustain a chronic infiltrate of a variety of $\mathrm{T}$ cell subsets. The CD4-IL-10 and CD8-TNF $\alpha$ subsets have been associated with reduced chlamydial clearance or oviduct pathology, respectively $[8,40]$. These data suggest that increased numbers of activated $\mathrm{cDC}$ result in increased numbers of $\mathrm{T}$ cells in the GT.

\section{The lack of CXCR5 causes increased cytokine production by NKT cells}

NKT cells respond as innate-like $\mathrm{T}$ cells within infected tissues by secreting an array of cytokines and chemokines upon TCR activation which results in the recruitment and/or activation of various immune cells including neutrophils and cDCs. This could possibly explain the increased neutrophil and activated $\mathrm{cDC}$ numbers seen in the GT of Cxcr5-/ - 4 days after infection (Fig. 1C-E) [12]. We tested this by activating splenocytes in vitro with chlamydiae elementary bodies (EBs). Using IFN- $\gamma$ production as a marker of early NKT cell activation, we found that splenic cultures from Cxcr5-/- mice produced approximately 10-fold greater amounts of IFN- $\gamma$ compared to cultures from WT mice (Fig. 4A). We then used various means to deplete cultures of NKT cells in order to determine if NKT cells were the source of increased IFN- $\gamma$. Depletion of iNKT cells using the $\alpha$-GalCerCDld tetramer, depleted greater than $90 \%$ of type I NKT cells and significantly diminished IFN- $\gamma$ production. Stimulation with $\alpha$-GalCer increased production of IFN- $\gamma$ above that of WT cells and demonstrated that iNKT cells contribute in part, to the increased IFN- $\gamma$ production. We examined IFN $\gamma$ production from all NKT cells by blocking CDld antigen presentation with antiCD1d antibody. This further reduced IFN- $\gamma$ levels. In addition, the combination of both treatments reduced IFN- $\gamma$ production from Cxcr5-1- splenocytes to that of untreated WT control splenocyte cultures following incubation with $C$. muridarum EB which indicates that the majority of the IFN $\gamma$ secreted by splenocytes in response to EB stimulation was secreted by iNKT and type II NKT cells (Fig. 4A).

We analyzed other cytokine and chemokines in the splenic cultures of Cxcr5-/- and WT cells stimulated with EB and found they produced a variety of inflammatory cytokines and chemokines that are found in the GT and that attract neutrophils (IL-17 $\alpha$ ) and cDC (CXCL12: ligand for CXCR4; CGL3 \& CCL5: ligand for CGR5; CCL2: ligand for CGR2) [41,42]. Cultures from $\mathrm{Cxcr} 5-1-$ mice produced a 2 to 10 -fold increase in the level of most of cytokines and chemokines analyzed (Fig. 4B). We then examined supernatants depleted with $\alpha$ GalCer-tetramer and blocked with anti-CDld antibody (designated "treated" groups) to deplete all NKT cells. We found that the combination of depletion+blocking of CDld function reduced cytokines and chemokine levels which were found to be at or below that of WT cultures (Fig. 4B). Only secretion of IL-6 was partially reduced by NKT cell depletion. Increased cytokine and chemokine levels we observed here could be produced directly by activated NKT cells or their interaction with other cell types, such as dendritic cells, as shown by others [43]. These data suggest that C. muridarum activates NKT cells which recruits early inflammatory cells, particularly neutrophils and activated cDC to the GT. 

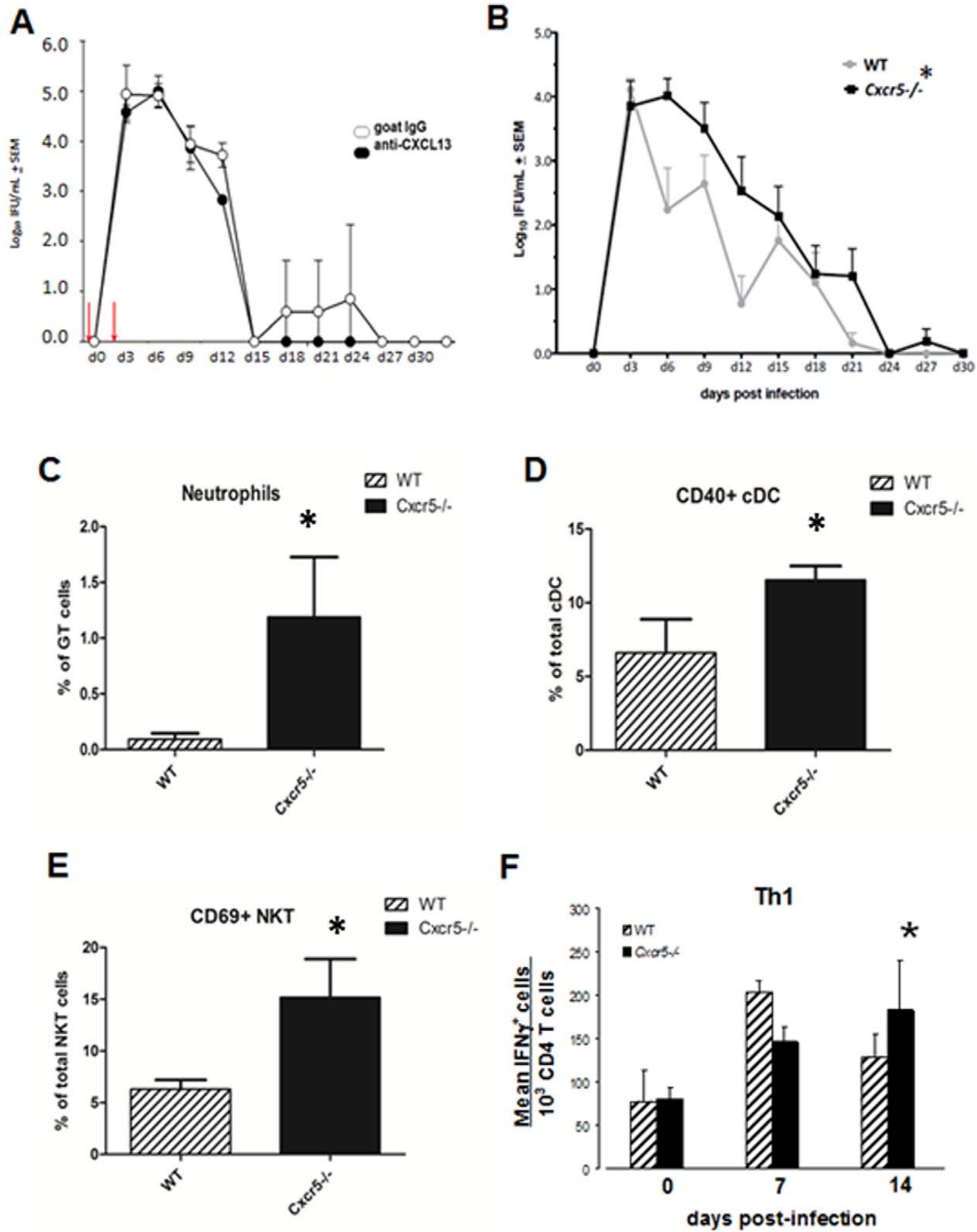

Figure 1. Disruption of the CXCL13-CXCR5 axis alters bacterial burden in $\mathrm{CXCr5}-/-$ mice. Vaginal swabs were collected throughout the course of infection in BALB/c mice given i.p. injections (day -1 and 2, red arrow) of anti-CXCL13 Ab or irrelevant control Ab. Not significant by 2-way repeated measures ANOVA, $n=3 / g r p$. (B) Vaginal swabs were collected throughout the course of infection in $C x c r 5-/-$ and WT mice. ${ }^{*} p<0.05$ by 2 way repeated measures ANOVA, $n=11 /$ grp. Experiments were and repeated 5 times. (C-E) Single cell suspensions of whole GT lymphocytes were stained for flow cytometric identification of neutrophils $\left(\mathrm{Gr}-1^{+} \& \mathrm{CD} 11 \mathrm{~b}^{+}\right) ; \mathrm{CDC}\left(\mathrm{CD} 11 \mathrm{c}^{+}, \mathrm{CD} 11 \mathrm{~b}^{+}, \mathrm{CD} 3^{-}, \mathrm{CD}^{-} 9^{-} \mathrm{CD} 40^{+}\right)$and activated NKT cells $(\alpha-$ GalCer tetramer, NK1.1 $1^{+}, \mathrm{CD}^{+} ; \mathrm{CD}^{+} 9^{+}$). Dotplots were gated on singlet lymphocytes and the above markers. Bar graphs show the percent of neutrophils, $\mathrm{CD} 40^{+} \mathrm{CDC}$ and $\mathrm{CD} 69^{+} \mathrm{NKT}$ over the indicted denominator $\pm \mathrm{SD}$ in GT. ${ }^{*} p<0.01$ as determined by Bonferroni's $\mathrm{t}$-test, $\mathrm{n}=4$ pools of two mice/group. (F) Mice were vaginally infected with C. muridarum and lymphocytes were isolated at various times following infection from the whole GT. Cells were stimulated ex vivo with PMA and ionomycin and characterized by flow cytometry. Dotplots were gated on CD3 and CD4. Bars show the mean frequency of Th1, IFN $\gamma^{+}$cells per group \pm SD of 4 mice/group. ${ }^{*} p<0.05$ as determined by Bonferroni's modified t-test. doi:10.1371/journal.pone.0047487.g001 
A
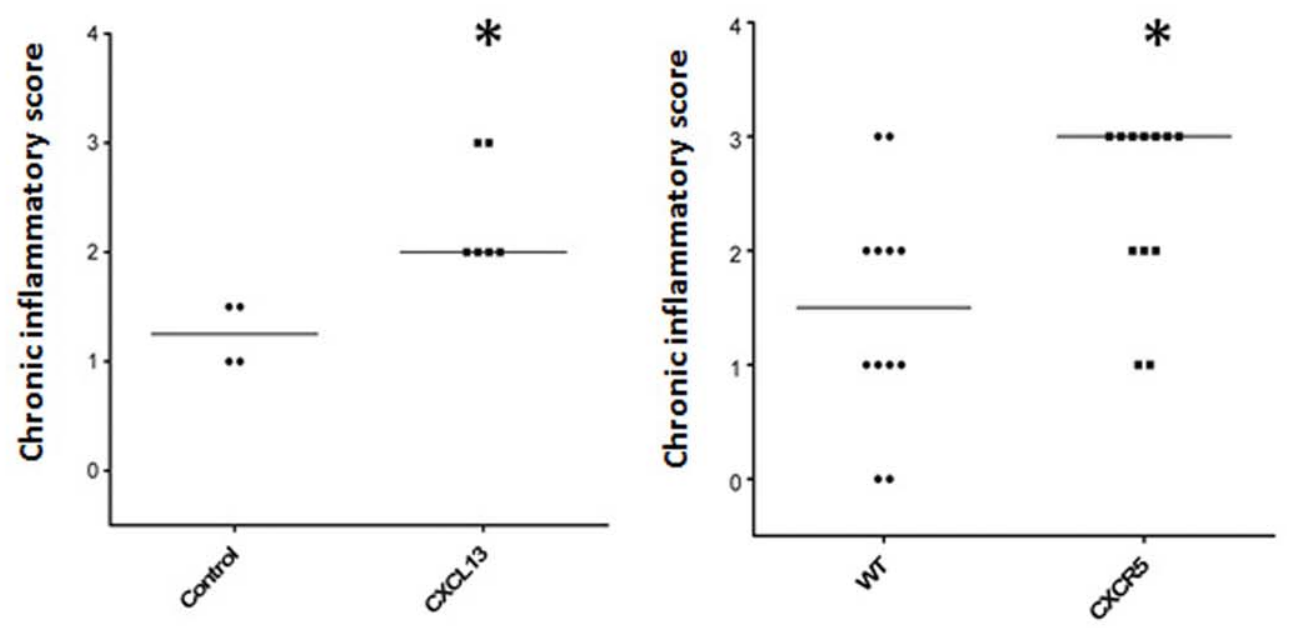

B
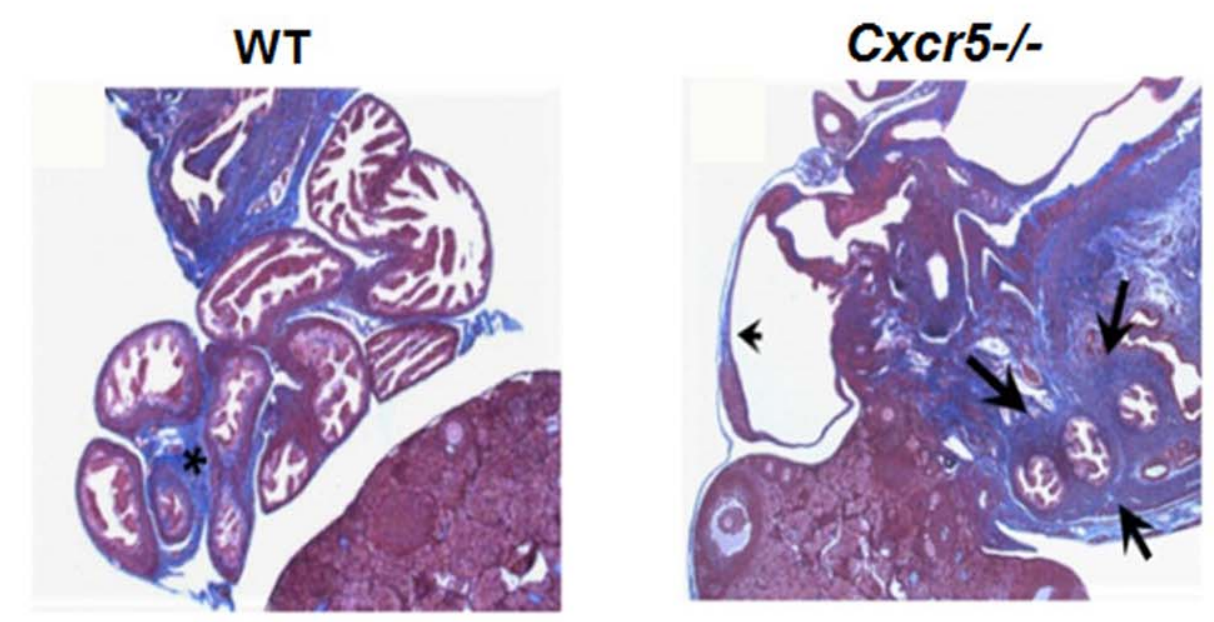

C

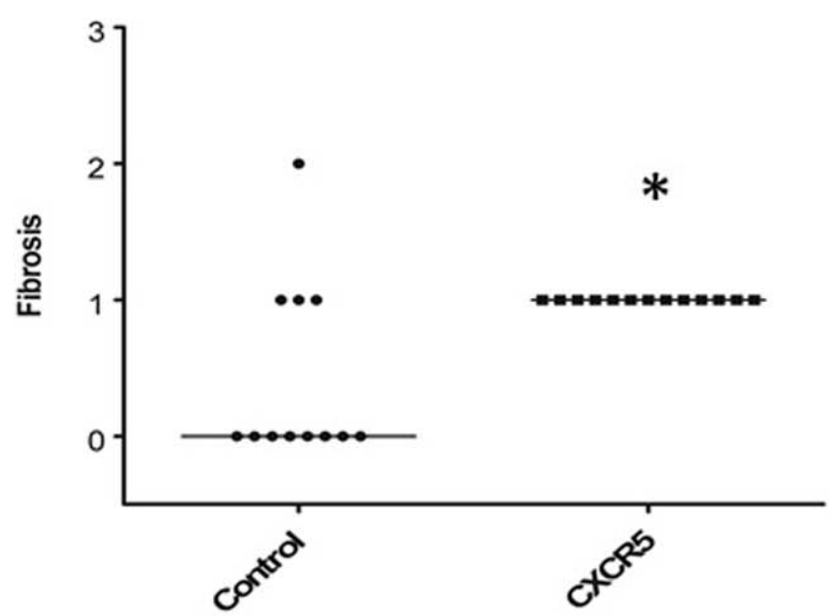

Figure 2. Disruption of the CXCL13-CXCR5 axis increased UGT pathology. GTs were harvested 49 days after infection and processed en bloc for paraffin sections. (A) Scatter plot and median of chronic inflammatory scores of BALB/c mice treated with anti-CXCL13 Ab versus an irrelevant control $\mathrm{Ab}$ or $\mathrm{C} 56 \mathrm{BL} / 6$ WT mice versus $\mathrm{Cxcr5}-/-$ mice from hematoxylin and eosin stained slides. ${ }^{*} p<0.05$, Mann-Whitney, $\mathrm{n}=3-6 \mathrm{mice}$ or 12 oviducts/group. (B) Photomicrograph of trichrome stained sections from oviducts 49 days after infection of C57BL/6 (WT) or Cxcr5-/- mice. Asterisk (WT) and arrows (Cxcr5-/-) show fibrosis and arrowhead (Cxcr5-/-) depicts a dilated oviduct. Sections are at 20×. (C) Fibrosis scores of C56BL/6 WT mice and $\mathrm{Cx}$ (r5 $5-/-$ mice from trichrome stained slides. ${ }^{*} p<0.01$, Mann-Whitney, $\mathrm{n}=6$ mice or 12 oviducts/group. doi:10.1371/journal.pone.0047487.g002 
A
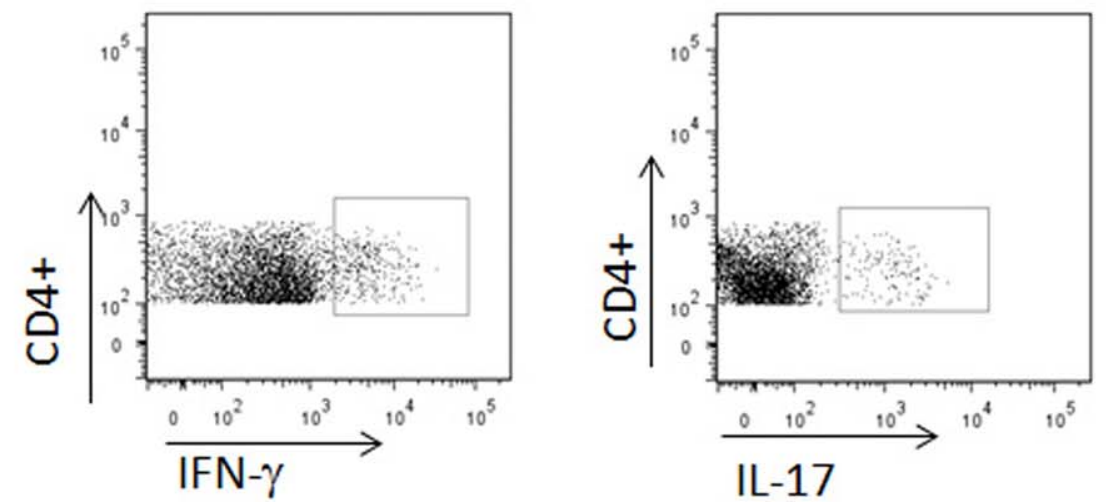

IL-17
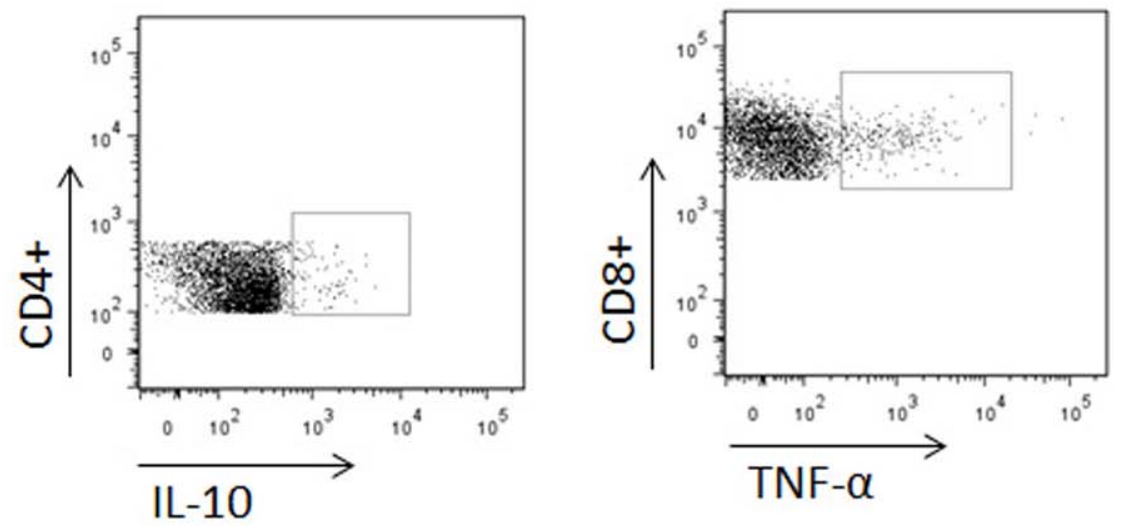

B

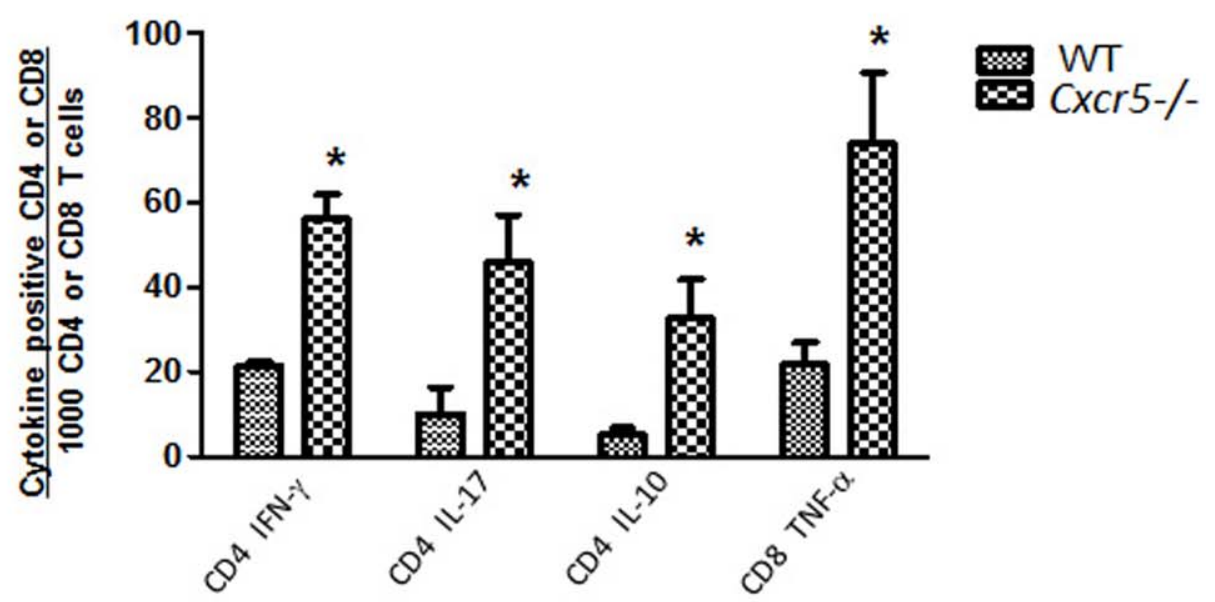

Figure 3. Lymphocytes accumulate in the oviducts of Cxcr5-I- mice following infection. GTs were harvested 49 days after vaginal infection with C. muridarum and used to isolate lymphocytes from the oviducts. (A) Representative dotplots of oviduct lymphocyte subsets stained against surface markers and intracellular cytokines. Cells were gated on $\mathrm{CD}^{+} \mathrm{CD} 4^{+}$or $\mathrm{CD}^{+} \mathrm{CD} 8^{+}$cells. (B) The number of lymphocyte subsets as determined in panel $\mathrm{B}$, were compared between groups. Bars equal the mean \pm SD. ${ }^{*} p<0.01$ (Bonferroni's modified $\mathrm{t}$ test). $\mathrm{n}=3-4$ oviduct pools/ group.

doi:10.1371/journal.pone.0047487.g003 
A

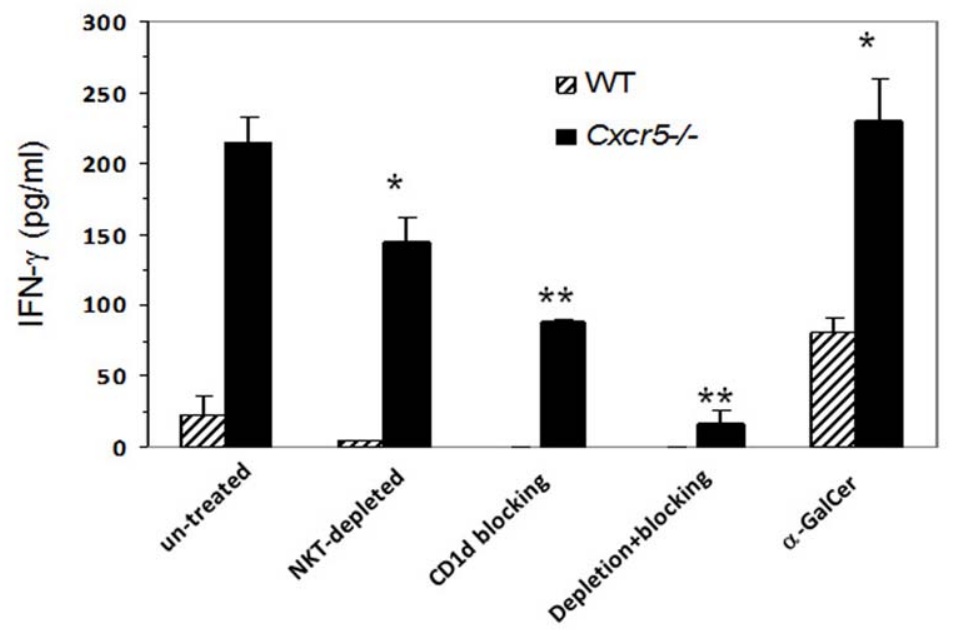

B

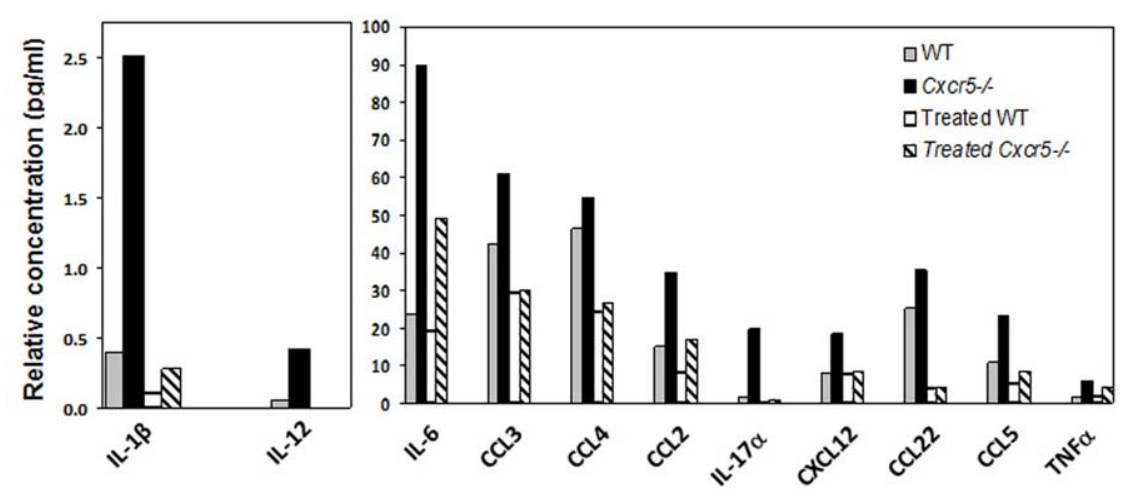

Figure 4. In vitro depletion of NKT cell function abrogates increased production of IFN $\gamma$ and other cytokines and chemokines in CXcr5-/-. Lymphocytes were isolated from spleens and treated with various conditions to deplete NKT cells to $95 \%$ purity. Cells were cultured with EB for 3 days. (A) The level of IFN $\gamma$ in cell culture supernatants among groups with the indicated NKT cell depleting/blocking treatment. Each treated group was compared to its own untreated counterpart using Bonferroni's modified $t$ test, ${ }^{*} p<0.05,{ }^{* *} p<0.01, \mathrm{n}=4$ mice/group. (B) Multiple cytokines and chemokines levels were measured in supernatants from $\alpha$-GalCer depleted plus anti-CD1d treated cell cultures (Depletion+blocking). doi:10.1371/journal.pone.0047487.g004

\section{C. muridarum activates iNKT and type II NKT cells and the} lack of NKT cells in Cd1d-/- mice reduces UGT pathology

We determined if chlamydial organisms contained antigens which directly activated iNKT and II NKT cells in a cell-free system as described [32]. Our analysis found that a C. muridarum sonicate induced IL-2 secretion and the activation of murine NKT hybridomas. Figure 5A shows one of two iNKT cell hybridoma V $\alpha 14 \mathrm{~V} \beta 8.2(1.2,2 \mathrm{C} 12)$ and a type II NKT cell hybridoma (19) [44]. The finding from this assay, which contains only a TCR ligand presented on CDld molecules and is free of any antigen presenting cells, indicates that $C$. muridarum organisms contain glycolipid antigens which can bind and activate iNKT and II NKT cells. It is likely that C. muridarum contains at least 2 glycolipids since type II NKT cells do not recognize iNKT cell ligands [19]. The increased bacterial burden seen early after infection in Cxcr5-/- mice (Fig. 1B) could contribute to the activation of NKT cells. Cd1d-/- mice, which do not contain any NKT cells, were given a genital infection with C. muridarum to determine whether their absence influences oviduct dilation, fibrosis or bacterial burden in the GT. We found that oviduct dilation and fibrosis were significantly reduced in mice that lacked
NKT cells (Fig. 5B). Monitoring bacterial burden with vaginal swabs showed that $C d 1 d-/-$ mice had an increase in bacterial burden (Fig. 5C) and confirms that NKT cells are involved in $C$. muridarum genital infection as previously shown using $C d 1 d-/-$ mice [45].

GXCR5 +10950 T > G (rs3922) correlates with lack of tubal infertility following $G$. trachomatis infection in humans. There is considerable variability in both susceptibility to acquiring a C. trachomatis infection and development of GT pathology following infection $[36,46,47]$. To determine if the genetic variation in the $C X C R 5$ gene contributes to this variability in C. trachomatis infected humans we undertook a single-polymorphic nucleotide (SNP) analysis for genetic variation in the CXCR5 gene using TaqMan analysis. We examined CXCR5 SNPs in 1940 females from The Netherlands and Finland with chlamydial genital infection. We analyzed three SNPs in the human CXCR5 gene; +3439 $\mathrm{G}>\mathrm{T},(\mathrm{rs} 497916),+9086 \mathrm{~T}>\mathrm{C},(\mathrm{rs} 12363277)$ and $+10950 \mathrm{~T}>\mathrm{C} \quad(\mathrm{rs} 3922)$ which tag $96.6 \%$ of the haplotypes spanning $7.6 \mathrm{~KB}(\sim 41 \%)$ of the CXCR5 gene. The distribution of the SNPs and haplotypes in our study population is shown in Tables S1 and S2. We evaluated these SNPs for contribution to the susceptibility of $C$. trachomatis genital infection by comparing women attending a STD clinic for potential uncomplicated $C$. 
A

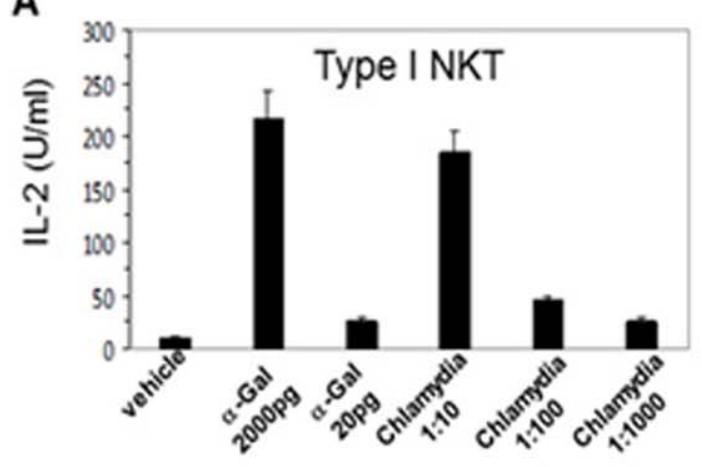

B

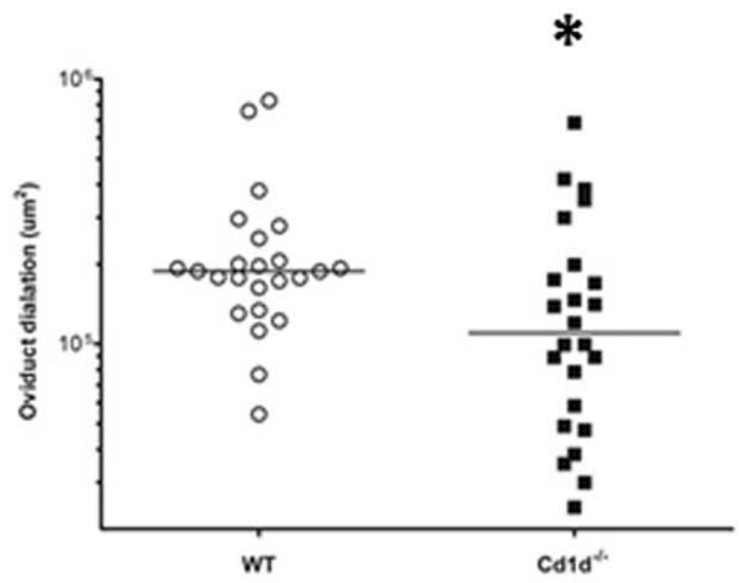

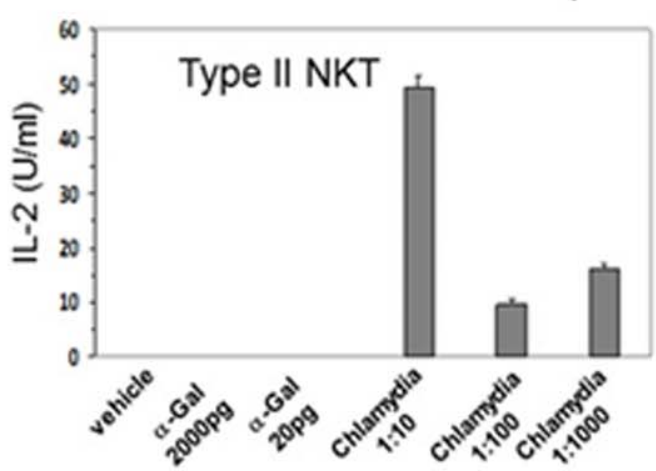

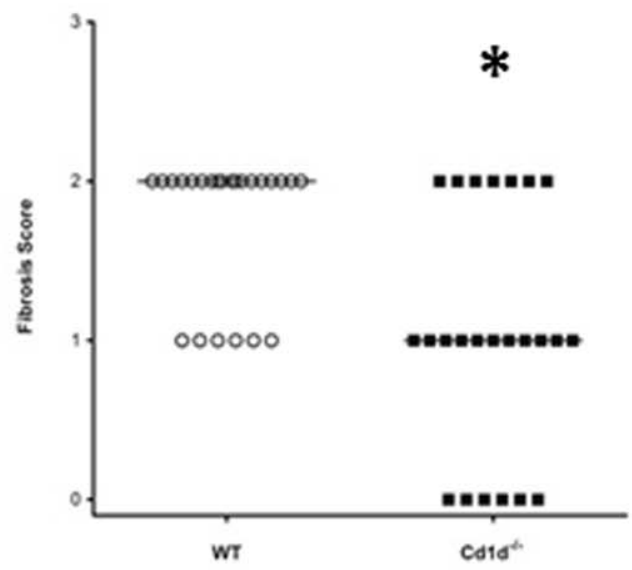

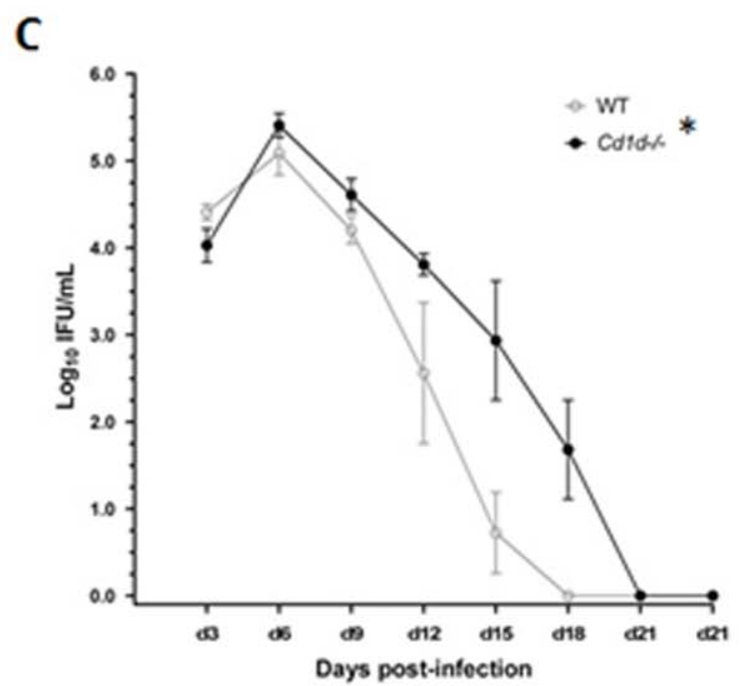

Figure 5. C. muridarum activates iNKT \& type II NKT cells in vitro and in vivo. (A) Various dilutions of $C$. muridarum sonicate or $\alpha$-Gal was added to cultures of type I NKT cell hybridoma 1.2 and a type II NKT cell hybridoma 1.9. IL-2 was measured in triplicate by ELISA. Experiments were and repeated 2-3 times. (B) Scatter plot of oviduct diameter and fibrosis scores from WT mice and Cxcr5-/- mice obtained from hematoxylin and eosin and trichrome stained slides, respectively. ${ }^{*} p<0.05$, Mann-Whitney, $n=6$ mice or 12 oviducts/group. (C) Vaginal swabs were collected throughout the course of infection in WT and $C d 1 d-/-$ mice. ${ }^{*} p<0.01$ by 2 -way repeated measures, $\mathrm{n}=6$ mice/group. doi:10.1371/journal.pone.0047487.g005

trachomatis infection. As shown in Figure 6A, carriage of CXCR5 $+10905 \mathrm{~T}>\mathrm{C}(\mathrm{rs} 3922)$ did not differ significantly between women with and without $C$. trachomatis genital infection. However, other alleles did influence susceptibility since carriage of the CXCR5
+9086 $\mathrm{T}>\mathrm{C}(\mathrm{rs} 12363277)$ allele was significantly reduced in $C$. trachomatis infected women compared to controls (Table S1). C. trachomatis infected women had a significantly lower frequency of the CXCR5 haplotype III and a trend of lower frequency in 
A

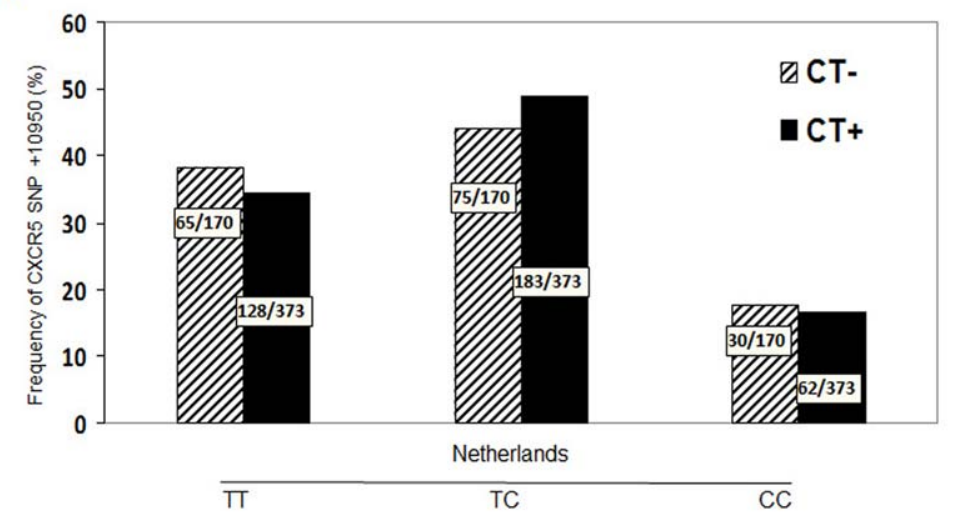

B

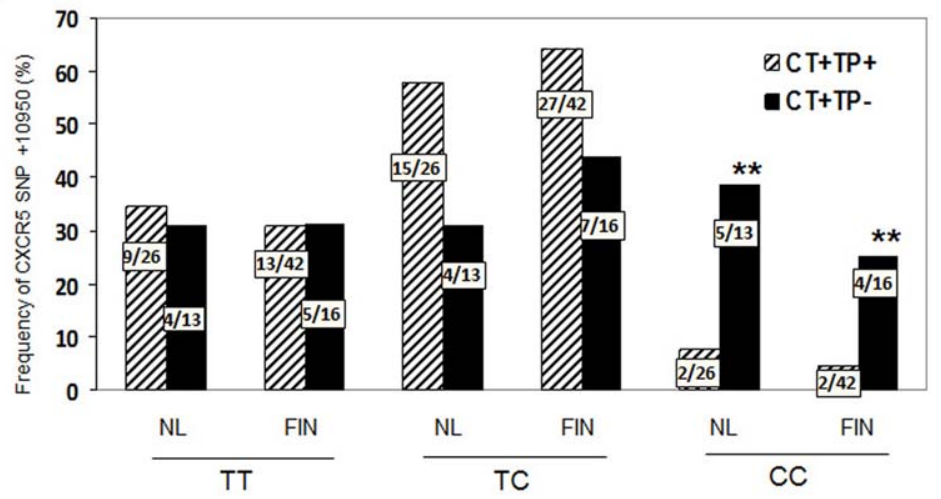

Figure 6. Distribution of the CXCR5 SNP+10950 T>C (rs3922) in all three cohorts. Genomic DNA was extracted from peripheral blood. Distribution of CXCR5 SNP+10950 T>C (rs3922) was determined in samples (A) women with and without a positive C. trachomatis PCR on cervical swab, $n=543$ or (B) women from The Netherlands $(n=56, p: 0.03 ;$ OR $0.1,95 \% C l: 0.02-0.82)$ and Finland $(n=114, p: 0.04 ;$ OR 0,$2 ; 95 \% C l: 0.2-0.9)$ that were positive for $C$. trachomatis and clinical evidence of subfertility. Statistics for both groups combined $(p: 0.002 ; \mathrm{OR}=0.1 ; 95 \% \mathrm{Cl}: 0.04-0.5 .9)$ by $\chi 2$ and Fisher Exact test, (CT: C. trachomatis; TP: Tubal pathology; NL: Netherlands, FIN: Finland. doi:10.1371/journal.pone.0047487.g006

CXCR5 haplotype IV compared to CT negative women (Table S2). These results suggest that women carrying CXCR5 haplotype III to have reduced severity of $C$. trachomatis infections while the CXCR5 +10950 (rs3922) SNP does not contribute to susceptibility of acquiring a genital infection with $C$. trachomatis.

We next evaluated whether different variants of the CXCR5 gene correlated with the development of tubal pathology following chlamydial genital infection. We identified that CXCR5 +10950 $\mathrm{T}>\mathrm{C}$ (rs3922) was differentially distributed between women who developed tubal infertility following $C$. trachomatis infection versus those that did not following CT infection. Women developing tubal infertility had a statistically significant decrease in the frequency of CXCR5 +10950 CC, both in the cohort from the Netherlands and the cohort from Finland (Fig. 6B). Possessing CXCR5 SNP +10950 (rs3922) with base pair CC, appears to protect against development of tubal pathology following infection. Although the functional consequences, i.e., gain or loss of CXCR5 chemokine function with SNP $+10950 \mathrm{~T}>\mathrm{C}$ (rs3922) is not known, the data presented here are consistent with the murine data and suggest that the CXCR5 gene influences chlamydial genital infection and tubal pathology in humans.

\section{Discussion}

We have identified a novel form of immune regulation in the GT that depends on the chemokine receptor, CXCR5, in mice and humans. In the absence of this receptor, NKT cell activation is increased following C. muridarum infection of mice and results in increased cytokine and chemokine production which could attract increased numbers of neutrophils and activated $\mathrm{cDC}$ to the GT early after infection. Although Cxcr5-/- mice had increased chlamydial burden in the GT, equal numbers of $\mathrm{EB}$ were used to activate NKT cells in vitro in WT and Cxcr5-/- mice and there was still significant NKT cell activation as shown by IFN $\gamma$ production. Neutrophils have been shown to induce GT inflammation and fibrosis and although we do not find occlusion fibrosis, we do find differences in oviduct dilation in the absence of NKT cells $[6,7]$. The increased number of activated $\mathrm{cDC}$ could contribute to the increased numbers of $\mathrm{T}$ cells found in the oviducts and increased chronic inflammatory scores measured in the UGT.. Although CXCR5 is expressed on a subset of NKT cells (Fig. S1) [48], CXCR5 could be expressed by another cell type which impacts NKT cell activation and will be investigated in future studies.

Activation of NKT cells induces numerous functions including interaction with other cell types as shown in Chlamydia infections [49]. Our data in Cxcr5-/- mice shows an increase in iNKT cell activation as defined by expression of CD69. This difference is confined to activated iNKT cells since we did not find a difference in the total number of NKT cells between Cxcr5-/- and WT mice. Also, the lack of CXCR5 did not prevent trafficking of activated iNKT cells to the GT indicating that CXCR5 is not 
present on the subset of NKT cells in the GT or that other chemokine receptors compensate. In addition, our data imply that signaling thorough CXCR5 is important for regulating the activation state and cytokine/chemokine secretion of iNKT cells. There are precedents for a proposed role for a chemokine receptor in regulating iNKT cell activity. For example, CXCR6 and its ligand have been shown to regulate the homeostasis of iNKT cells in the liver and trafficking to that site was not affected [50].

The presence of CDld in the GT of humans and the finding that it is a target of degradation by the chlamydiae CPAF suggests that NKT cells are important cells to regulate during genital infection [51,52]. Bilenki, L. et al. [45] showed that activated iNKT cells enhanced chlamydial growth following infection of the mouse pathogen, C. muridarum which was reversed in CD1d-/mice. They found that activation of iNKT cells induced a Th2type cytokine milieu which enhanced $C$. muridarum lung infection, delayed eradication of the organism including development of a Thl response and induced lung inflammation [45]. These findings support our work in $C d 1 d-/-$ mice. In contrast, our findings differed from a study by Wang et. al., which showed that activation of iNKT with $\alpha$-GalCer during genital infection increased production of Thl cells and slightly reduced bacterial burden but there was no data on UGT pathology or use of knockout mice [14]. This can be explained by comparing $\alpha$ GalCer stimulation which is not as conclusive as studies in 7 $\alpha 18-/-$ mice (target on iNKT cells) and those in Cd1d-/mice (target all NKT cell subsets) which target different subsets of NKT cells. Also, the many subsets of NKT cells may be functioning at the same time during $C$. muridarum infection which additionally confounds the information among various models. We also found direct evidence that $C$. muridarum infection activates iNKT cells and it was recently reported that $C$. muridarum glycolipid exoantigen (GLXA) also activated iNKT cells in a CDld-cell free assay [13]. Future studies are planned to identify these antigens using mass spectrophotometric techniques.

CXCR5 is expressed on B cells, T helper follicular cells and NKT cells [53] which localize in germinal centers and are important for antibody class switching by conventional or B-2 B cells [54]. As expected Cxcr5-/- mice given a genital infection with $C$. muridarum produce significantly less $C$. muridarum specific IgG showing that these mice have defective T-dependent and/or T-independent antibody production (data not shown). We also compared the number of CD4 cells in spleens of WT and Cxcr5-/ - to determine whether the lack of CXCR5 impacts the CD4 cell compartment. The percent of CD4 cells was slightly increased in Cxcr5-/- mice even before infection and more profoundly after infection suggesting that although the number of $\mathrm{T}$ helper follicular cells was absent in Cxcr5-/ - mice this did not markedly reduce number of CD4 $\mathrm{T}$ cells in the $\mathrm{T}$ cell compartment before and after infection.

This is the first study to provide direct evidence that antigens contained within chlamydial EB directly activate type II NKT cells subsets. iNKT and type II NKT cells are activated by $C$. muridarum EB suggesting that they contain at least two glycolipid antigens since iNKT and type II NKT have diverse TCR [55]. After entering host cells, chlamydiae intercept the host exocytic pathway and acquire various types of host lipids (phosphatidylinositol, phosphatidylcholine, cardiolipin and sphingolipids) for incorporation into bacterial cell walls and inclusion membrane and are necessary for growth [56-58]. Chlamydiae also contain enzymes that modify host-derived single chain fatty acids to the microbial form of branched chain fatty acids [59]. Additional studies have shown that chlamydiae can synthesize limited phospholipids: phosphatidylethanolamine, phosphatidylserine and phosphatidyl- glycerol including a CDP-diacylglycerol [60]. It will be important to identify chlamydial glycolipids that are presented by CDld to define how they influence genital infection.

We have also shown a similar influence of CXCR 5 on tubal pathology in humans. Women carrying the variant allele of CXCR5 +10950 CG did not develop the level of tubal pathology seen in subfertile women after CT infection. Interestingly, humans with the CXCR5 SNP+10950 T>C (rs3922), were equally susceptible to $C$. trachomatis genital infection compared to carriers of CCR5 SNPs [34]. Other studies have also found a SNP analysis of other chemokine genes correlates to tubal pathology. Barr et. al., found that the CCR5-related inflammatory response was demonstrated to be crucial for the development of tubal factor infertility [34]. They showed that in women with anti-chlamydial IgG responses, tubal pathology correlated with a low incidence of functional CCR 532 deletion $(7 \%)$, while women without tubal pathology had higher incidence of the CCR $5 \Delta 32$ deletion $(31 \%)$. Thus, in mice and humans the inflammation associated with CXCR5 and CCR5 function may predispose to development of complications of chlamydial infection, such as tubal factor infertility.

The host response is determined by interaction of pathogenassociated molecular patterns (PAMP) of chlamydiae and components of the innate host response. This interaction in turn, is based on individual genetic variation. Other studies have identified additional genes which also contribute to the variability in acquiring a chlamydial infection and immunopathology. Recently, Bailey et. al. [61] estimated the relative contribution of host genetics to the total variation in lymphoproliferative responses to chlamydial antigens by analysing these responses in 64 Gambian pairs of twins from trachoma-endemic areas. Proliferative responses to serovar A EB antigens were estimated in monozygotic and dizygotic twin pairs. They found a stronger correlation and lower within-pair variability in these responses in monozygotic compared to dizygotic twin pairs. The heritability estimate was 0.39, suggesting that host genetic factors contributed almost $40 \%$ of the variation. This study reinforces the concept of compiling genetic traits that influence infection and genital tract pathology for the development of a sub-fertility risk profile to advance disease prevention profiles and identify individuals for immune-modulatory therapeutics. This approach is currently the focus of EpiGenChlamydia in Europe.

There is a strong association between repeated $C$. trachomatis genital infection and development of tubal inflammation and infertility [4,5]. A combination of bacterial factors, host factors, epidemiologic and demographic factors, such as co-infections, and the mutual interaction of these factors influence this association [62]. Additionally, there are reported inter-individual differences in the clinical course of $C$. trachomatis genital infection such as; transmission, symptoms, persistence or clearance of infection, and the development of late complications $[4,63,64]$. It is difficult to correlate these to persistence of infection, especially when the detected serovar is not identical to the previous one [63-66]. Possibly repeated activated of NKT cells with multiple serovars following chlamydial genital infection in those with altered in CXCR5 expression and function could be responsible for interindividual differences. There is great variability in the frequency of Va24-J $\alpha 18$ iNKT cells in the peripheral blood of humans $(0.001-$ $3.0 \%$ ) and this suggests that differences occur in iNKT cell development, maturation and/or differentiation [67,68]. It is possible that frequency and type of infections plus genetic differences in Cxcr5 gene influence iNKT cell activation in humans [12]. This knowledge will be beneficial for the design of therapeutic strategies and vaccine development against Chlamydia infection. 
Our study is the first describing the protective effect of $C X C R 5$ gene polymorphisms in the development of C. trachomatis infection and late complications of this disease. In this genetically exploratory study using well defined clinical cohorts and only one gene, having an in vitro proof of association, we had decided not to "overdo" by using the most stringent statistical approach. The additional strength on this study is that our genetic association is confirmed in a second independent cohort, something which is in most studies is not even done. As we have shown in the knockout mouse model, an increased NKT activity leads to an increased bacterial burden in the GT and late complications of this disease. In humans, carriage of the variant allele, $+10950 \mathrm{~T}>\mathrm{C}$, might result in an altered function of the CXCR5 gene, and thereby an altered expression of NKT cells thus leading to fewer late complications of $C$. trachomatis infections such as tubal pathology. It is not known if $+10950 \mathrm{~T}>\mathrm{C}$ SNP of CXCR 5 gene results in a gain or loss of function. Although the exact pathways and mechanism(s) need to be elucidated, Cxcr5 knockout mice appear as a viable model for understanding the pivotal role of CXCR5. We therefore hypothesize that in humans, the mechanisms underlying the course of disease are similar as in Cxcr 5 knockout mice. Therefore, more studies are needed of human CXCR5 genetic polymorphisms on the function of this chemokine receptor.

\section{Supporting Information}

Table S1 Distribution of the GXGR5 SNPs in an STD cohort from Amsterdam two tubal pathology cohorts. Genomic DNA was extracted from peripheral blood and PCR was performed for three CXCR5 SNPs; +3439 C>T (rs497916), +9086 $\mathrm{T}>\mathrm{C}$ (rs12363277), and $+10950 \mathrm{~T}>\mathrm{C}$ (rs3922). ap:0.0487; OR 0.5, 95\%CI: 0.3-1,0; bp: 0.03; OR 0.1, 95\%CI: 0.02-0.82; cp: 0.04; OR 0,$2 ; 95 \%$ CI: $0.2-0.9$. Groups were compared using $\chi 2$ and Fisher Exact test, where appropriate. $\mathrm{p}<0.05$ was considered statistically significant. CT: C. trachomatis; TP: Tubal pathology. (PDF)

\section{References}

1. CDC GR (2011) Chlamydia Prevention: Challenges and Strategies for Reducing Disease Burden and Sequelae. WWMR Morb Mortal Wkly Rep. pp. 370-373.

2. WHO (2001) Global Prevalence and Incidence of Selected Curable Sexually Transmitted Infections: Overview and Estimates (World Health Organization, Geneva, 2001)

3. US Department of Health and Human Services DoSP (2007) Sexually Transmitted Disease Surveillance, 2007. Atlanta, GA: Centers for Disease Control and Prevention.

4. Westrom L, Joesoef R, Reynolds G, Hagdu A, Thompson SE (1992) Pelvic inflammatory disease and fertility. A cohort study of 1,844 women with laparoscopically verified disease and 657 control women with normal laparoscopic results. Sex Transm Dis 19: 185-192.

5. Burstein GR, Gaydos CA, Diener-West M, Howell MR, Zenilman JM, et al. (1998) Incident Chlamydia trachomatis infections among inner-city adolescent females. JAMA 280: 521-526.

6. Ramsey KH, Sigar IM, Schripsema JH, Shaba N, Cohoon KP (2005) Expression of matrix metalloproteinases subsequent to urogenital Chlamydia muridarum infection of mice. Infect Immun 73: 6962-6973.

7. Shah AA, Schripsema JH, Imtiaz MT, Sigar IM, Kasimos J, et al. (2005) Histopathologic changes related to fibrotic oviduct occlusion after genital tract infection of mice with Chlamydia muridarum. Sex Transm Dis 32: 49-56.

8. Murthy AK, Li W, Chaganty BKR, Kamalakaran S, Guentzel MN, et al. (2011) Tumor Necrosis Factor Alpha Production from CD8+ T Cells Mediates Oviduct Pathological Sequelae following Primary Genital Chlamydia muridarum Infection. Infect Immun 79: 2928-2935.

9. de la Maza L, Pal S, Khamesipour A, Peterson EM (1994) Intravaginal inoculation of mice with the Chlamydia trachomatis mouse pneumonitis biovar results in infertility. Infect Immun 62: 2094-2097.

10. Morrison RP, Feilzer K, Tumas DB (1995) Gene knockout mice establish a primary protective role for major histocompatibility complex class II-restricted responses in Chlamydia trachomatis genital tract infection. Infect Immun 63: 46614668 .
Table S2 Haplotypes of GXGR5 in in two tubal pathology cohorts and an STD cohort from Amsterdam. Genomic DNA was extracted from peripheral blood and PCR was performed for three CXCR5 SNPs; +3439 C > T (rs497916), +9086 $\mathrm{T}>\mathrm{G}(\mathrm{rs} 12363277)$ and $+10950 \mathrm{~T}>\mathrm{C}(\mathrm{rs} 3922)$. CXCR5 haplotypes were inferred using PHASE v2.1.1 [62,63] and SNPHAP [64]. ap:0.0097, OR: 0.18, 95\% CI: 0.05-0.66. Groups were compared using $\chi 2$ and Fisher Exact test, where appropriate. $\mathrm{p}<0.05$ was considered statistically significant. Haplotype IV was not significantly different from CT- from the FCT: C. trachomatis; TP: Tubal pathology.

(PDF)

Figure S1 $7.5 \%$ of NKT cells express GXCR5. Representative dotplots showing NKT cell gating and expression of CXCR5, 7 days after infection. Single cell suspensions of lymphocytes were stimulated with PMA and ionomycin, and stained for NKT cells using $\alpha$-GalCer tetramer, CD3, CD4, CD8, NK1.1, GD69 and CXCR5. Dotplots were gated on CD3+, NK1.1+, -GalCer-tetramer+ cells.

(TIF)

\section{Acknowledgments}

We thank Hosti Poya, Ronika Sitapatrick and Su-Yin Kok for excellent technical assistance and Martin Lipp and Uta E. Höpken for CXCR5 breeding pairs.

\section{Author Contributions}

Conceived and designed the experiments: JJ OK SO CIC J. Pleijster JAL HS J. Paavonen MK SAM KAK. Performed the experiments: JJ OK SO CIC AK GL AF J. Pleijster NR HS AT. Analyzed the data: JJ OK SO CIC AK GL AF J. Pleijster JAL HS J. Paavonen MK SAM KAK. Contributed reagents/materials/analysis tools: MK. Wrote the paper: JJ OK SO CIC MK SAM KAK.

11. Rank Roger G, Whittum-Hudson Judith A (2010) Protective Immunity to Chlamydial Genital Infection: Evidence from Animal Studies. J Inf Dis 201: $168-177$.

12. Kronenberg M, Kinjo Y (2009) Innate-like recognition of microbes by invariant natural killer T cells. Curr Opin Immunol 21: 391-396.

13. Peng Y, Zhao L, Shekhar S, Liu L, Wang H, et al. (2012) The glycolipid exoantigen derived from Chlamydia muridarum activates invariant natural killer $\mathrm{T}$ cells. Cell Mol Immunol 9: 361-366.

14. Wang H, Zhao L, Peng Y, Liu J, Oi M, et al. (2012) Protective Role of $\alpha$ galactosylceramide Stimulated Natural killer T cells in Genital Tract Infection with Chlamydia muridarum. FEMS Immunol Med Microbiol.

15. Yang X (2007) Natural killer T (NKT) cell subsets in chlamydial infections. Adv Exp Med Biol 601: 243-246.

16. Godfrey DI, MacDonald HR, Kronenberg M, Smyth MJ, Van Kaer L (2004) NKT cells: what's in a name? Nat Rev Immunol 4: 231-237.

17. Bendelac A, Savage PB, Teyton L (2007) The biology of NKT cells. Annu Rev Immunol 25: 297-336.

18. Cohen NR, Garg S, Brenner MB, Frederick WA (2009) Chapter 1 Antigen Presentation by CD1: Lipids, T Cells, and NKT Cells in Microbial Immunity. Adv Immunol: Academic Press. pp. 1-94.

19. Godfrey DI, Kronenberg M (2004) Going both ways: immune regulation via CD1d-dependent NKT cells. J Clin Invest 114: 1379-1388.

20. Mazzucchelli L, Blaser A, Kappeler A, Scharli P, Laissue JA, et al. (1999) BCA-1 is highly expressed in Helicobacter pylori-induced mucosa-associated lymphoid tissue and gastric lymphoma. J Clin Invest 104: R49-54.

21. Vermi W, Facchetti F, Riboldi E, Heine H, Scutera S, et al. (2005) Role of dendritic cell-derived CXCL13 in the pathogenesis of Bartonella henselae B-rich granuloma. Blood: 2005-2004-1342.

22. Rupprecht TA, Pfister HW, Angele B, Kastenbauer S, Wilske B, et al. (2005) The chemokine CXCL13 (BLC): a putative diagnostic marker for neuroborreliosis. Neurology 65: 448-450.

23. Kazuya S, Takashi K, Tetsuya M, Hiroaki K, Ikuo T (2004) Different chemokine expression in lethal and non-lethal murine west nile virus infection. J Med Virol 74: 507-513. 
24. King M, Poya H, Rao J, Natarajan S, Butch A, et al. (2009) CXCL13 expression is induced by Chlamydia trachomatis infection of the female reproductive tract. Drugs Today (Barc) 45: 105-115.

25. Zheng B, Ozen Z, Zhang X, De Silva S, Marinova E, et al. (2005) CXCL13 neutralization reduces the severity of collagen-induced arthritis. Arthritis Rheum 52: $620-626$.

26. Maxion HKM, Liu W, Chang MH, Kelly KA (2004) The infecting dose of Chlamydia muridarum modulates the innate immune response and ascending infection. Infect Immun 72: 6330-6340.

27. Kelly KA, Walker JC, Jameel SH, Gray HL, Rank RG (2000) Differential regulation of CD4 lymphocyte recruitment between the upper and lower regions of the genital tract during Chlamyida infection. Infect Immun 68: 1519-1528.

28. Darville T, Andrews CW, Lafoon KK, Shymasani W, Kishen LR, et al. (1997) Mouse strain-dependent variation in the course and outcome of chlamydial genital tract infection is associated with differences in host response. Infect Immun 65: 3065-3073.

29. Darville T, O’Neill JM, Andrews CW, Jr., Nagarajan UM, Stahl L, et al. (2003) Toll-like receptor-2, but not toll-like receptor-4, is essential for development of oviduct pathology in chlamydial genital tract infection. J Immunol 171: 61876197.

30. Jiang J, Kelly KA (2012) Isolation of Lymphocytes from Mouse Genital Tract Mucosa. J Vis Exp. Sept 3:(67), pii 4391. doi: 10.3791/4391.

31. Matsuda JL, Naidenko OV, Gapin L, Nakayama T, Taniguchi M, et al. (2000) Tracking the response of natural killer T cells to a glycolipid antigen using CD1d tetramers. J Exp Med 192: 741-754.

32. Kinjo Y, Illarionov P, Vela JL, Pei B, Girardi E, et al. (2011) Invariant natural killer $\mathrm{T}$ cells recognize glycolipids from pathogenic Gram-positive bacteria. Nat Immunol 12: 966-974.

33. van Doornum GJ, Schouls LM, Pijl A, Cairo I, Buimer M, et al. (2001) Comparison between the LCx Probe system and the COBAS AMPLICOR system for detection of Chlamydia trachomatis and Neisseria gonorrhoeae infections in patients attending a clinic for treatment of sexually transmitted diseases in Amsterdam, The Netherlands. J Clin Microbiol 39: 829-835.

34. Barr EL, Ouburg S, Igietseme JU, Morré SA, Okwandu E, et al. (2005) Host inflammatory response and development of complications of Chlamydia trachomatis genital infection in CCR5-deficient mice and subfertile women with the CCR5delta32 gene deletion. J Microbiol Immunol Infect 38: 244-254.

35. Murillo LS, Land JA, Pleijster J, Bruggeman CA, Pena AS, et al. (2003) Interleukin-1B (IL-1B) and interleukin-1 receptor antagonist (IL-1RN) gene polymorphisms are not associated with tubal pathology and Chlamydia trachomatisrelated tubal factor subfertility. Hum Reprod 18: 2309-2314.

36. Ohman H, Tiitinen A, Halttunen M, Lehtinen M, Paavonen J, et al. (2009) Cytokine polymorphisms and severity of tubal damage in women with Chlamydiaassociated infertility. J Infect Dis 199: 1353-1359.

37. Moniz RJ, Chan AM, Kelly KA (2009) Identification of dendritic cell subsets responding to genital infection by Chlamydia muridarum. FEMS Immunol Medical Microbiology 55: 226-236.

38. Ohl L, Henning G, Krautwald S, Lipp M, Hardtke S, et al. (2003) Cooperating Mechanisms of CXCR5 and CCR7 in Development and Organization of Secondary Lymphoid Organs. J Exp Med 197: 1199-1204.

39. Ansel KM, Ngo VN, Hyman PL, Luther SA, Forster R, et al. (2000) A chemokine-driven positive feedback loop organizes lymphoid follicles. Nature 406: 309-314.

40. Igietseme JU, Ananaba GA, Bolier J, Bowers S, Moore T, et al. (2000) Suppression of endogenous IL-10 gene expression in dendritic cells enhances antigen presentation for specific Th1 induction: potential for cellular vaccine development. J Immunol 164: 4212-4219.

41. Scurlock AM, Frazer LC, Andrews CW, O'Connell CM, Foote IP, et al. (2011) Interleukin-17 contributes to generation of Th1 immunity and neutrophil recruitment during Chlamydia muridarum genital tract infection but is not required for macrophage influx or normal resolution of infection. Infect Immun 79: 1349-1362.

42. Maxion HK, Kelly KA (2002) Differential chemokine expression in distinct regions of the murine genital tract during Chlamydia trachomatis infection. Infect Immun 70: 1538-1546.

43. Dalaker K, Gjnnaess H, Kvile G, Urnes A, Anestad G, et al. (1981) Chlamydia trachomatis as a cause of acute perihepatitis associated with pelvic inflammatory disease. Br J Vener Dis 57: 41-43.

44. Brossay L, Naidenko O, Burdin N, Matsuda J, Sakai T, et al. (1998) Structural requirements for galactosylceramide recognition by CD1-restricted NK T cells. J Immunol 161: 5124-5128.
45. Bilenki L, Wang S, Yang J, Fan Y, Joyee AG, et al. (2005) NK T Cell Activation Promotes Chlamydia trachomatis Infection In Vivo. J Immunol 175: 3197-3206.

46. Darville T, Hiltke TJ (2010) Pathogenesis of Genital Tract Disease Due to Chlamydia trachomatis. J Infect Dis 201: S114-S125.

47. Ohman H, Tiitinen A, Halttunen M, Paavonen J, Surcel HM (2011) Cytokine gene polymorphism and Chlamydia trachomatis-specific immune responses. Hum Immunol 72: 278-282.

48. Johnston B, Kim CH, Soler D, Emoto M, Butcher EC (2003) Differential Chemokine Responses and Homing Patterns of Murine TCR \{alpha\}\{beta\} NKT Cell Subsets. J Immunol 171: 2960-2969.

49. Joyee AG, Uzonna J, Yang X (2010) Invariant NKT Cells Preferentially Modulate the Function of CD8 $\{$ alpha $\}+$ Dendritic Cell Subset in Inducing Type 1 Immunity against Infection. J Immunol 184: 2095-2106.

50. Geissmann F, Cameron TO, Sidobre S, Manlongat N, Kronenberg M, et al. (2005) Intravascular immune surveillance by CXCR6+ NKT cells patrolling liver sinusoids. PLoS Biol 3: e113.

51. Kawana K, Matsumoto J, Miura S, Shen L, Kawana Y, et al. (2008) Expression of CDld and Ligand-Induced Cytokine Production Are Tissue Specific in Mucosal Epithelia of the Human Lower Reproductive Tract. Infect Immun 76: 3011-3018.

52. Kawana K, Quayle AJ, Ficarra M, Ibana JA, Shen L, et al. (2007) CDld degradation in Chlamydia trachomatis-infected epithelial cells is the result of both cellular and chlamydial proteasomal activity. J Biol Chem 282: 7368-7375.

53. Chang PP, Barral P, Fitch J, Pratama A, Ma CS, et al. (2012) Identification of Bcl-6-dependent follicular helper NKT cells that provide cognate help for B cell responses. Nat Immunol 13: 35-43.

54. Junt T, Fink K, Förster R, Senn B, Lipp M, et al. (2005) CXCR5-dependent seeding of follicular niches by $\mathrm{B}$ and Th cells augments antiviral $\mathrm{B}$ cell responses. J Immunol 175: 7109-7116.

55. Kronenberg M (2005) TOWARD AN UNDERSTANDING OF NKT GELL BIOLOGY: Progress and Paradoxes. Annu Rev Immunol 23: 877-900.

56. Hackstadt T, Scidmore MA, Rockey DD (1995) Lipid metabolism in Chlamydia trachomatis -infected cells: Directed trafficking of Golgi-derived sphingolipids to the chlamydial inclusion. Proc Natl Acad Sci USA 92: 4877-4881.

57. Hackstadt T, Rockey DD, Heinzen RA, Scidmore MA (1996) Chlamydia trachomatis interrupts an exocytic pathway to acquire endogenously synthesized sphingomyelin in transit from the Golgi apparatus to the plasma membrane. EMBO Journal 15: 964-977.

58. van Ooij C, Kalman L, van Ijzendoorn, Nishijima M, Hanada K, et al. (2000) Host cell-derived sphingolipids are required for the intracellular growth of Chlamydia trachomatis. Cell Microbiol 2: 627-637.

59. Wylie J, Hatch G, McClarty G (1997) Host cell phospholipids are trafficked to and then modified by Chlamydia trachomatis. J Bacteriol 179: 7233-7242.

60. International S (2011) BioCyc Database Collection. Chlamydia trachomatis 434/Bu Pathways.

61. Bailey RL, Natividad-Sancho A, Fowler A, Peeling RW, Mabey DC, et al. (2009) Host genetic contribution to the cellular immune response to Chlamydia trachomatis: Heritability estimate from a Gambian twin study. Drugs Today (Barc) 45 Suppl B: 45-50.

62. Brunham RC, Pourbohloul B, Mak S, White R, Rekart ML (2005) The Unexpected Impact of a Chlamydia trachomatis Infection Control Program on Susceptibility to Reinfection. J Infect Dis 192: 192:1836-1844.

63. Golden MR, Whittington WL, Handsfield HH, Hughes JP, Stamm WE, et al. (2005) Effect of expedited treatment of sex partners on recurrent or persistent gonorrhea or chlamydial infection. N Engl J Med 352: 676-685.

64. Morré SA, van den Brule AJ, Rozendaal L, Boeke AJ, Voorhorst FJ, et al. (2002) The natural course of asymptomatic Chlamydia trachomatis infections: 45\% clearance and no development of clinical PID after one-year follow-up. Int J STD AIDS 13 Suppl 2: 12-18.

65. Morré SA, Van Valkengoed IG, Moes RM, Boeke AJ, Meijer CJ, et al. (1999) Determination of Chlamydia trachomatis prevalence in an asymptomatic screening population: performances of the LCx and COBAS Amplicor tests with urine specimens. J Clin Microbiol 37: 3092-3096.

66. Moore B, Coffey M, Christensen P, Sitterding S, Ngan R, et al. (2000) GM-CSF regulates bleomycin-induced pulmonary fibrosis via a prostaglandin-dependent mechanism. The Journal of Immunology 165: 4032-4039.

67. Chan AC, Serwecinska L, Cochrane A, Harrison LC, Godfrey DI, et al. (2009) Immune characterization of an individual with an exceptionally high natural killer T cell frequency and her immediate family. Clin Exp Immunol 156: 238245.

68. Lee PT, Putnam A, Benlagha K, Teyton L, Gottlieb PA, et al. (2002) Testing the NKT cell hypothesis of human IDDM pathogenesis. J Clin Invest 110: 793-800. 